リータ・レビ - モンタルチー二は、間 違いなく、20 世紀を代表する科学者 の一人だ。あえて女性科学者と強調す る必要もない。1950 年代に彼女が格 闘した神経成長因子（NGF）の発見と 単離によって、光の後の生命科学は、 大きな新しい道が開かれた。

神経細胞は成長して複雑なネットワー クが形成されていくが、「なぜ、どのよ うに?」という根本的な問いかけが、彼 女の仕事から始まったのだ。1986 年 にノーベル賞を受賞した。

2009 年 4 月 22 日に 100 歳の誕 生日を迎えたリー夕。いまなお現役をつ づける彼女の生き方は、私たちに限り ない希望と勇気と教訓を与えてくれる。

(編集部)

\title{
ONE HUNDRED YEARS OF RITA
}

\section{0 歳を迎えたしビ-モンタルチ一二女史}


2006 年 11 月 18 日の朝、イタリア政府 全体が小柄なリータに注目していた。当 時わずか 1 議席差で議会の多数を制して いた中道左派ロマーノ・プローディ内閣が 予算案を上程し、上院終身議員であるリー タが、その運命を決する 1 票を握ってい たからである。

数日前、政府が土壇場で行った科学資 金削減の決定を取り消さない限り、予算 に対する支持を撤回する、とリータは語つ た。リータ対プローディの綱引きは、結局 はリータの勝ちとなった。投票の朝、彼女 はいつものようにきちんと整った服装で議 場に現れ、案内役に腕を支えられて堂々 と自らの席につき、修正予算案に賛成票 を投じた。2007 年度予算が確定し、イタ リアの科学のための戦いに勝利するととも に、野党連合の一角をなす右派国民同盟 の有力者ストラーチェに肘鉄を食らわせた のだった。

というのは、数週間前、ストラーチェは リータの自宅に松葉杖を送りつけることを 表明し、イタリア国内で大問題になってい た。松葉杖は、リータが弱体化したプロー ディ政府を支えていること、そして彼女の 高齢の象徵だと言い放った。ストラーチェ は高齢すぎるリータに議決権は認められな いと考えていた。

そのとき 97 歳だったリータは、決して 自分が高齢すぎるとは思っていなかった。 ノーベル賞受賞者として初めて 100 歳に 到達する 2009 年 4 月 22 日になっても、 当然のことながらそう思っていないだろ う。イタリアはもちろん世界中を見渡して も、彼女のような科学者はおそらく初めて の存在だ。

1909 年にトリノの裕福なユダヤ人家庭 に生まれたリータは、自らの人生を切り開 くために懸命に戦った。最初の戦いの相 手は、女性に高等教育を受けさせる必要 はないと考える頑迷な父親だった。次は、 ユダヤ人を大学から追放したムッソリー二 の人種法で、リー夕は潜伏生活を強いら れた。その次の相手は、彼女が発見した
神経成長因子 (NGF) の存在を認めよう としない科学界であった。

後に彼女は、神経成長因子の発見に より 1986 年のノーベル医学生理学賞を 同僚のStanley Cohen と共同受賞する。 「これは非常に大きな発見で、細胞間の 情報伝達過程を解明する上で全く新しい 局面が開かれました」と 30 年以上にわ たってリータを尊敬し続けるスタンフォー ド大学（米国カリフォルニア州）の神経科 学者 Bill Mobley は語る。今日では数百 種類におよぶ成長因子が知られており、こ の種の因子が生物学のほぼすべての局面 で重要な㗢きを担っていることを明確に示 している。

リータはなお毎日仕事を続けている。 洗練された着こなし、スタイリッシュな 髮型、爪は完璧にマニキュアが施されて いる。毎朝、ローマ郊外にある彼女の 名を冠した研究所「European Brain Research Institute (EBRI)-Rita LeviMontalcini」に出勤する。午後は、 1992 年に彼女が設立したアフリカ女性 のための教育基金のオフィスがあるダウン タウンへと向かう。

100 歳になったことは、戦いをやめる 理由にならない。「これまでやってきたこ

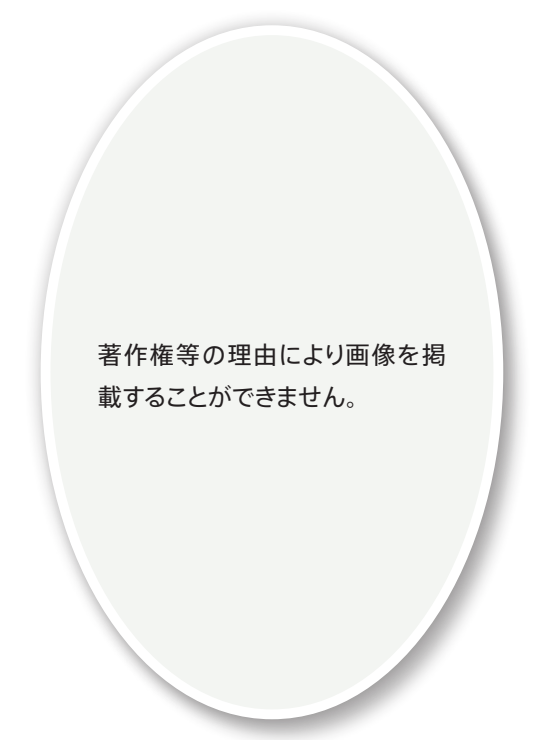

青春時代の Rita Levi-Montalcini は、医学校 に進学しようとして父親と戦った。
とで十分というわけではありません。未来 があるからです」とリー夕は言う。彼女は、 イタリアの科学を明るくするための活動で あれば、上院議員という肩書きを利用す ることに躊躇しなかった。いま彼女は、自 身にとってより大切なもののために戦って いる。それは 2002 年に設立し、現在財 政難に陥っている EBRI の存続である。

\section{自らの手で人生を切り開く}

リー夕の研究キャリアの中では、米国が多 くの部分を占めている。しかし、初期と後 期についてはイタリアが拠点となった。高 校卒業から 3 年後、彼女はようやく父親 を説得して医学を勉強することを認めさ せ、1930 年にトリノ大学に入学した。最 初の指導教官は、著名な神経組織学者 Giuseppe Leviであった。彼女は、自 叙伝『In Praise of Imperfection』(邦 題「美しき未完成」）の中で、Leviを「大 先生」と呼んでいる。

Levi は、積極的に発言する反ファシズ ム主義者であり、癎㿎を起こして周囲を驚 かせることでも知られていた。彼は、リー タが最初に熱心に取り組んだ研究テーマ である「神経系の発生」へと導いた人物 だった。Levi の行き届いた指導の下、彼 女の成功にとって重要なカギとなる神経 細胞の銀染色法を習得した。この技術 は、19世紀末期にCamillo Golgi が 開発し、その後、スペインの神経科学者 Santiago Ramon y Cajal が改良したも ので、これによって個々の神経を顕微鏡下 で極めて明瞭に観察できるようになった。

1938 年になると、ムッソリーニの人種 法が制定され、すべてのユダヤ人が大学 やその他の公的機関から追放された(こ の時 Levi も追放された)。リータも単独 で研究を始めることになった。人里離れ たバレンシア（スペイン）に仮設実験室 を作り、自力で研究を進めたCajal の話 に触発され、彼女もまた、実家の寝室を 実験室に改造したのである。しばらくして Levi がトリノに戻ると、ここでLevi と共 

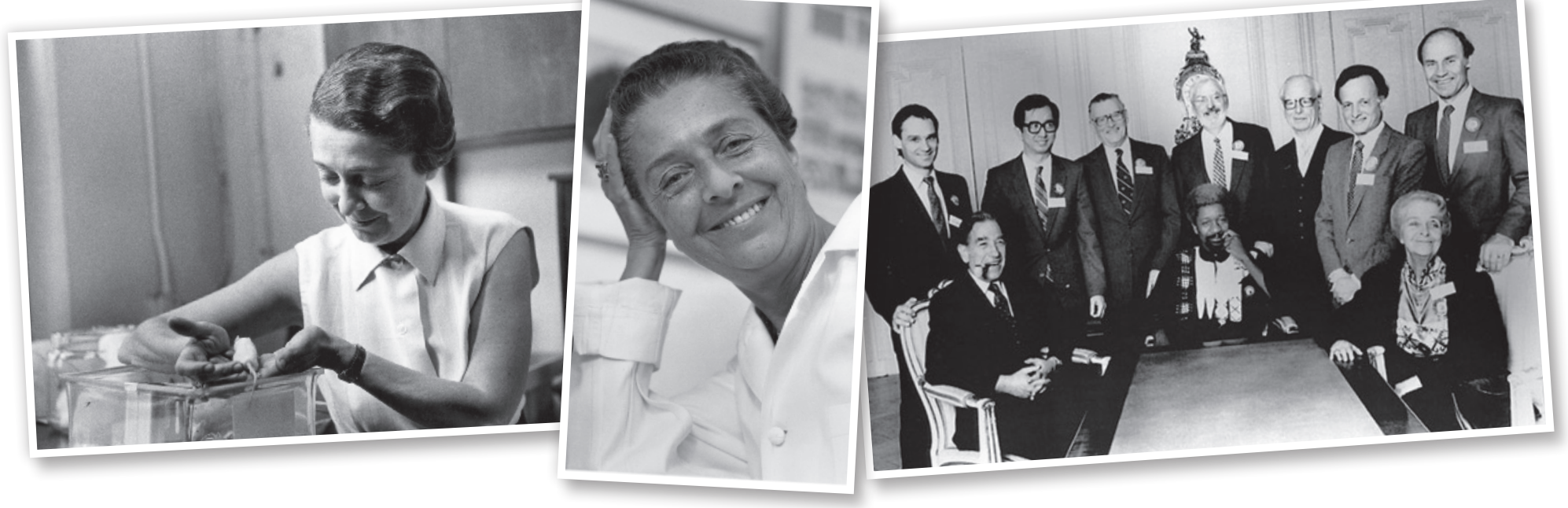

ワシントン大学 (セントルイス) で研究生活を送った 1950 年代 (左) と 1960 年代 (中)。Stanley Cohen と彼女 (テーブルをはさんで左右に座っている) は、 1986 年にノーベル賞を受賞した (右)。

同研究するようになった。

リータの研究課題は決まっていた。発生 中の胚の春髄から伸びた神経が、肢芽、 つまり初期発生段階の肢（あし）に到達 する過程を調べることであった（神経は最 終的に肢芽を支配する)。彼女は、ワシン トン大学（米国ミズーリ州セントルイス） の発生学者Viktor Hamburger が数年 前に発表した心躍る論文 ${ }^{1} に$ に出ったば かりだった。Hamburgerは、ニワトリ 胚の肢芽を切除すると、神経節（脊髄か ら伸びる神経繊維を集合させ、最終目的 地へと誘導する微小な構造体）が萎縮す るという観察結果を得たのだ。そして、神 経支配される組織から放出される誘導因子 （彼の命名による）が、肢芽の切除によっ てなくなったために神経節が萎縮した、と 結論づけた。Hamburgerは、この誘導 因子が神経前駆細胞を増殖させ、ニュー ロンへ分化させるために必要だと提唱し たのである。

しかし Hamburger は、光学顕微鏡で 神経繊維を詳細に観察することができな かった。そこでリー夕は、銀染色法を使っ てこの実験を追試することに決めたのであ る。孵卵器、顕微鏡、少しばかりの実験 器具、そして二ワトリの受精卵を定期的に
補給すれば実験はできると、Cajal ばりに 考えた。縫い針を加工して微小メスと微小 へらを作り、それで切除実験してみると、 実は、神経節がすぐに萎縮するわけでは ないことがわかった。実際には、ニューロ ンは増殖・分化し、標的に向かって伸長 し始めるのだが、標的に到達する直前の ところで死滅していたのだ。そこでリータ は、問題は「誘導因子」の欠如ではなく、 通常は肢芽から放出される「成長促進因 子」の欠如が原因だと結論づけた 2 。

1942 年の終わり頃、爆撃が激しくなっ てリータの家族は地方に踈開せざるを得な くなった。そこでも彼女はくじけずに研究 を続け、自転車で農家を巡って受精卵を 買い集めた。唯一研究が中断されたのは、 イタリアが 1943 年に連合国側に降伏. 休戦したためにドイツ軍がイタリア北部に 侵攻した時であった。

戦争が終わるとリータはトリノに戻り、 Levi の助手となった。ところが助手とい う役どころは、36 歳になった彼女には 小さわしいものではなかった。そもそも 彼女の寝室内実験室では、Levi が彼女 の助手をつとめたこともあったからであ る。Hamburgerからの招待状は、こ うした状況から抜け出す糸口となった。
Hamburgerは、彼女とLeviが共同で 戦時中に発表した論文を読んでおり、追 試とさらなる実験ができるよう彼女を 1 学 期間セントルイスに呼んだのだった。

\section{インスピレーションが生み出す洞察力}

その間になされた害験がきっかけとな り、1 学期限りだったはずのリータのセ ントルイス滞在は 26 年に延びることに なる。Hamburgerの大学院生 Elmer Buekerは、肢芽と同じように成長の早 い別の組織断片でも、同じように神経繊 維が誘導されるのかどうか調べようとして いた。具体的には増殖中のマウス肉腫の 塊をニワトリ胚に移植したところ、神経繊 維が成長して、肢芽の場合よりも大量に 腫瘍塊の中に侵入したのである。ここか ら Bueker は、腫瘍の表面積の方がより 大きかったために、より多くの神経が腫瘍 に向かって伸長した、という仮説を導いた。

しかしリータは違った。彼女は抜群の直 観力で知られているが、Buekerの実験 を知って彼女のアンテナは震えた。神経繊 維の侵入の仕方がおかしいと思ったから だ。発生中の肢芽の中では神経は整然と 伸長したのに、腫瘍では、伸長が大規模. 無秩序で、神経繊維はランダムに枝分か 
れしていた。彼女は、発生中の肢芽から 放出されると自ら主張してきた成長促進因 子と類似の因子が、移植された腫瘍組織 からも放出されており、この因子が神経 節に拡散して神経繊維の成長を促してい るに違いない、と確信するようになる。

リータは、ニワトリ胚を包む膜の外側（漿 尿膜）に腫瘍を移植するという巧妙な方 法で、追試実験した。この部分は胚と物 理的に隔てられているが、この漿尿膜に は、胚に血液を送る血管が広がっている。 これは決定的な実験だった。神経が発芽 して無秩序に成長したからである。この結 果によって、腫瘍から放出された因子が 血液中に拡散し、胚に送られるという彼 女の理論が裏づけられたのだった ${ }^{3}$ 。「彼 女は、Buekerの実験デー夕に対して別 の解釈があることを明確に認識しており、 そのことを実証する方法もわかっていたの です」。コロビア大学（米国ニューヨー ク州）でニューロン分化を研究し、その 学生時代からリータと親交のあるLloyd Greene の言葉だ。

しかしリータの理論を真に実証するに は、受精卵よりも信頼性と柔軟性にすぐ れ、測定対象である種々の応答を定量化 できるような実験系が必要だった。彼女は、 単離ニワトリ胚神経節を培養する方法を学 びたいと考えたが、それが可能な研究所 を 1 か所しか知らなかった。そこで彼女は、 腫瘍をもつ 2 匹の生きた白マウスをハン ドバックに入れて、リオデジャネイロ行き の飛行機に乗り込んだ。リオデジャネイロ では、Levi の別の教え子が大きな組織培 養施設を運営していたからである。

リータは、リオデジャネイロで、単離神 経節の培養方法を学び、マウスの内腫断 片の近くで単離神経節を培養した。培養 を24 時間続けたところ、神経節から神 経繊維が成長して、まるで太陽のハロー (暈) のようになり、腫瘍と向かい合う 領域で神経繊維の密度が最も高くなった。 彼女は興奮に包まれた。当時、彼女が Hamburgerに宛てた多くの書簡には、
神経繊維のハローの美しいイラストが含ま れている。彼女のすぐれた芸術性は、そ の研究論文に付された手書きのイラスト、 そして自分でデザインした衣服にも明確に 見てとれる。

\section{懐疑から認知へ}

リータがリオデジャネイロから戻った頃 には、Hamburgerの研究グループに Cohen が加わっていた。リータとCohen は、その後 6 年間にわたり、腫瘍から放 出される因子の同定を目指して共同研究 を進めた。当時の科学界は神経促進因子 の存在に懷疑的であり、2人は、その確 かな化学的証拠を突きつけてやろうと固く 決意していた。のちに、リータとCohenは、 その目的の因子が、神経の大量成長を促 進するへビ毒とマウス唾液腺抽出物から大 量に放出されているという考えを発表した が、そのために科学界はますます懷疑の 念を強めてしまった。

多くの科学者にとって、要求される発想 の飛躍が大きすぎた。思いもよらない可 溶性因子が 1 つの組織から拡散し、神経 の特定のプロセスに強い影響を及ぼすと 言われても、そのまま信じることはできな かったのだ。「当時の学界では、そうした 生物学的作用が認められていなかった点 に留意してください。リータは、この因子 が腫瘍、ヘビ毒、それに多くの正常な組 織にも含まれているという考え方を提示し

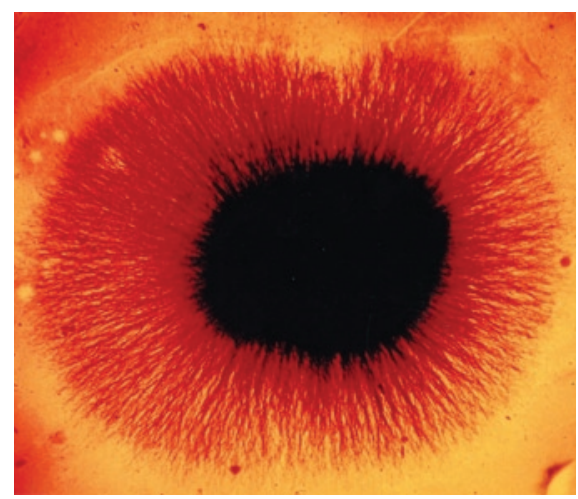

ハロー効果 : 彼女は、成長因子によって、ニワトリ 神経節から神経繊維が発芽することを発見した。
たわけですが、それがまともな生物学の 考え方だとは当時の人々にはどうしても思 えなかったのです」。こう説明するのは、 1969 年に初のタンパク質化学者として ワシントン大学に加わり、現在はカリフォ ルニア大学サンフランシスコ校に所属する Ralph Bradshaw である。

この因子に類似した別の因子（のち に上皮増殖因子 $\mathrm{EGF}$ と呼ばれる）が Cohen によって発見される ${ }^{4}$ と、ようやく リー夕の考え方に賛同する研究者が増え始 めた。1959 年には、Cohenと共同で、 精製された神経成長因子に対する抗血清 を作製した。この抗血清には、in vitroで のハロー形成を抑制する作用があり、また、 新生仔マウスに注射した実験では、神経 系と関連する部分が消失したのである ${ }^{5}$ 。

1971 年にBradshaw とリータの唯一 の博士課程の教え子である Ruth Hogue Angeletti が共同で、初期の自動アミノ 酸分析装置を使って神経成長因子タンパ ク質の構造決定に成功した ${ }^{6}$ 。これによっ てリータの考え方に対する科学界の最後 の疑念が解消されたのである。「リータの ような地位にある人なら、私たちの論文 の著者に加わると思ったのですが、彼女 はそうしませんでした。彼女らしいところ です」(Bradshaw)

リー夕は、米国科学界の雾囲気をとて も気に入っていたが、いつもイタリアと自 分の家族のことを恋しがっていた。1960 年代前半になると、彼女はセントルイス とローマの 2 か所を拠点として活動する ようになる。ローマでは、イタリアの主要 研究機関であるCNR が彼女のために研 究所を開設した。彼女の仕事のスタイル は、情け容赦なく、要求は㛜しく、熱意 にあふれていた。研究に最も熱が入って いた数十年間、彼女は、午前 7 時より早 い時間や夜遅くにも同僚を集めて、実験 について話し合った。しかしAngeletti は、リータの下での研究体制は残酷といっ たものではなく、インスピレーションにあ ふれていたと説明する。「当時の私は、意 


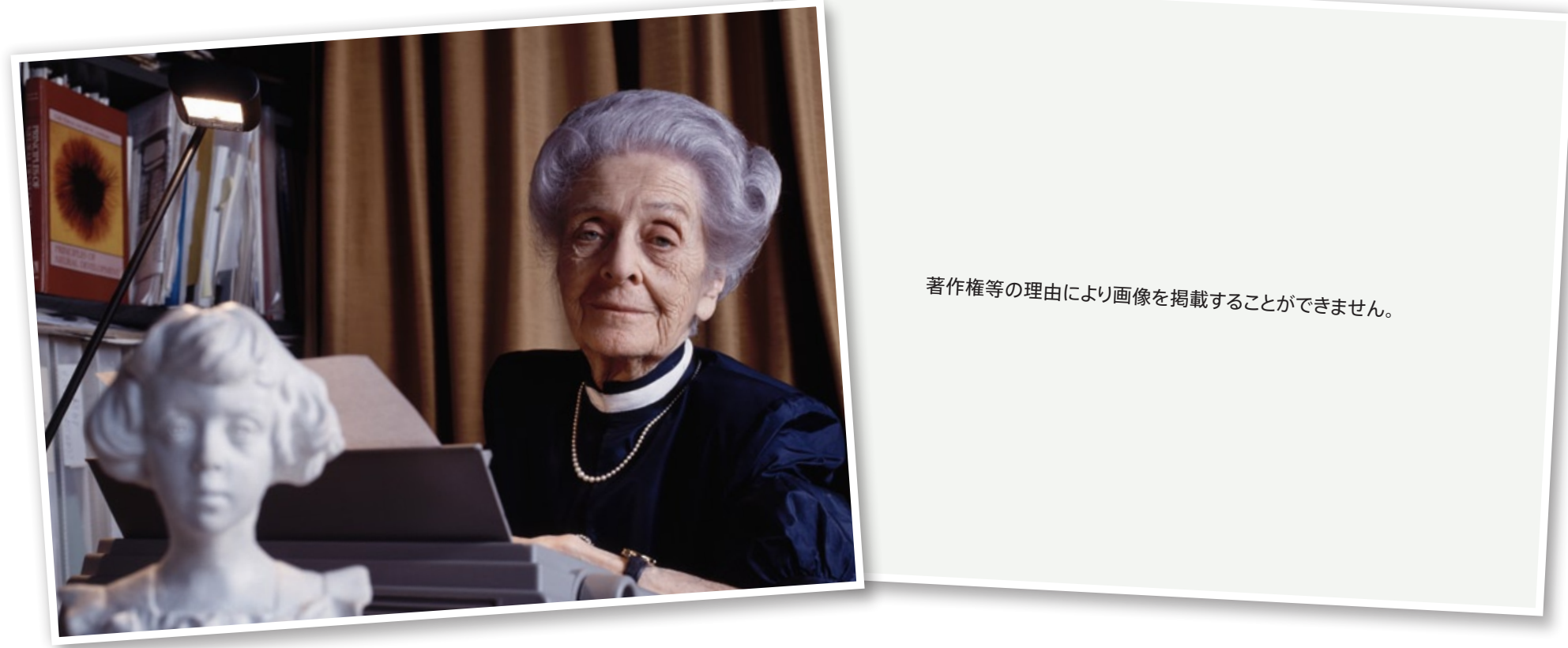

Rita Levi-Montalcini は、21 冊の一般向け書籍を執筆し、また自らの名を冠したイタリアの脳研究所で研究を続けている (右)。

欲旺盛なアメリカの若者でしたが、そんな 私でも、これほどひたむきな人を見たこと がありませんでした。今思うと、こんなに 才能にあふれ、開放的で、寛大な人と一 緒に研究ができたのは幸運なことでした」。 (Angeletti)

\section{けんかと仲直り}

ようやく成長因子の研究が立派な研究と 認められ、他の科学者が、この領域にどっ と押し寄せた時、リー夕は、満足するどこ ろか、自分のなわばりが侵略されているこ とに腹立たしく感じた。「正確な日付は覚 えていませんが、彼女は、私を含めて神 経成長因子のほとんどの研究者とけんか をしています」とBradshaw は当時を思 い起こす。Greeneも、リータが会議の 席で、聴衆に向かって、研究上の発見の 順序を説明することが多かったと話す。あ る講演会で、Greene の講演が終わると、 彼女が真っ先に手を挙げた。「彼女は質問 をしようとしたのではなく、神経成長因子 とその研究史に関する長い声明を行った のです。発言を続けながら舞台と演壇にじ りじりと近づき、あっという間に私の隣ま
でやってきて、マイクに向かって“質問” を続けました」。Greeneとしては、「わ きへ寄ってマイクを譲り、まゆをひそめて 彼女に最後まで話させる」しかなかった。

1980 年代前半になると、リー夕は、同 じ研究分野のすべての研究者と仲直りを 始めた、とBradshaw は言う。彼女と Bradshawのけんかは、彼女に見せず に発表してしまった彼の論文をめぐるもの だったが、彼女は、ある学会の席で 2 人 きりの雑談に誘い、その場で仲直りをして しまった。「私にとって緊張を強いられた 辛い時期が、これで終わりました。でもリー 夕は若いころ、大いなる疑いの目に耐え 忍んできたわけですから、自己防衛に走 らざるを得ない面があったと思います」と Bradshaw。彼女のその後の発見に対し ては、そんな目は向けられなかった。例 えば彼女は、神経成長因子が免疫系に大 きな影響を与えるという予想外の発見をし たが、それは、生物学における大きな転 換点となった ${ }^{7}$ 。

リータとCohen がノーベル賞を受賞す る頃には、彼女は、相当な数の研究者と 仲直りしていた。ところが受賞後に別の
問題が巻き起こった。彼女が、Leviや Hamburgerなどの研究者に謝意を表明 しなかったことに憤慨した人々がいたの である。100 歳まで生きた Hamburger は、彼を含めたノーベル賞の受賞が適切 と考えた人々もいた中で、彼との共同受賞 が適切でない理由をリータが公表してしま い、2 人の友情にひびが入ったと断言した。

\section{イタリア科学のために}

しかし、リータが永住するイタリアでは、 そのような批判は勢いを持たなかった。 その実績、並外れた個性、活力と雄弁さ から、彼女をイタリアの宝と考える人々は 多い。彼女が所属する CNR の研究所は、 イタリア国内で最大級の生物学研究セン ターとなった。彼女は、イタリアの科学の 水準を高めるために、あらゆるレベルで 努力を払う責任を進んで引き受けた。彼 女は半生にわたる筋金入りの社会主義者 であり、中道左派政権の首相を 2 回歴任 したプローディとも親交を持つようになっ た。2001 年に上院の終身議員に就任し て以来、議会での投票には必ず出席して、 脆弱なプローディの連立政権を支えた。 
リー夕は、科学における倫理、科学にお ける女性といった研究関連の社会問題に も取り組んでいる。リータ・レビ - モンタ ルチー二財団は、6000人以上のアフリカ 人女性の教育を支援してきた。それは「科

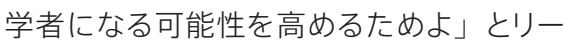
夕は言う。彼女は感性の鋭い書き手でも あり、21 冊の一般向け書籍を出版してい る。若い頃は本の虫で、古典小説のお気 に入りはエミリー・ブロンテの愛の悲劇『嵐 が丘』だった。ただ、ロマンティックな気 持ちは文学に限られており、医学校時代 に短い男女交際はあったものの、長期に わたるロマンスはなかった。1988 年の「オ ムニ」誌とのインタビューで、彼女は、2 人の優れた人間が結婚した場合であって も、「配偶者がより大きな成功を収めてい れば、そのことを恨んだりするかもしれま せん」と意味深長な発言を残している。

リータの果たせていない望みの 1 つは、 イタリア国内に、世界的に重要で運営状 態の良好な研究機関を遺産として残すこと である。イタリアの国立研究システムの多 くの部分は、資金不足、非効率と官僚主 義によって機能不全に陥っている。研究活 動の拡大をもくろんでいたサンタルチア研 究所 (口ーマ) は、リー夕の神経科学研 究所のために 10 年間、無償で施設を貸 与することを申し出た。この EBRI が今や 不安定な状態になっているのだ。リー夕は
政府が EBRI の運営資金を提供することを 期待していたが、プローディ政権は、そ の崩壊直前の 2008 年に一度だけ 300 万ユーロ（約 4 億 8000 万円）の寄付金 を提供しただけで、その他の高額の寄付 は得られなかった。右派のベルルスコー 二政権は研究にはあまり関心がなく、リー タ・レビ - モンタルチーニの名前も通用し なかった。

EBRIには現在、スタッフが 28 人おり、 年間赤字が 20 万ユーロ (約 2600 万円) にのぼっている。今年に入って、トリノ大 学の神経科学者 Piergiorgio Strata が、 状況を好転させる使命を担って科学ディ レクターに就任した。彼は今後の成功に 自信をもっており、「研究所が生き残るに は、おそらく年間 300 万ユーロ（約 3 億 9000 万円）が必要です」と話す。確固 たる決意のリータはStrataに厚い信頼を 寄せており、「私は楽観主義者です。研究 所を存続させる方法が見つかる望みは、 まだあります」。

\section{素敵なリー夕}

リータの聴力と視力は衰えてきたが、頭脳 は明晰である。EBRIでは、神経成長因子 の進化上の起源を明らかにするための研 究プロジェクトを走らせている。数人の若 手研究者が、一連の無脊椎動物に神経成 長因子が存在するかどうかを調べるため
に力を貸している。若手研究者は、リー タとほぼ毎日話ができることに満足してい る。EBRI で働く博士研究員の 1 人である Francesca Paoletti は、「リー夕は、私 たちにとって着想の源泉、インスピレーショ ンなのです」と話す。

こうした研究者がリータを幸せにしてい る。「死めことは怖くありません。こんなに 長く研究ができるなんて、私は特別に恵ま れているのだと思います。死めのが明日で あろうと、1 年後であろうと、同じことです。 大事なのは、私が残していくメッセージで あり、私の研究を引き継いでくれる若手の 研究者なのです」。リー夕は、そう話すと、 タコの組織に含まれる神経成長因子の顕 微鏡写真を握り締め、友人の腕に支えられ て去っていった。その足取りは、ゆっくりで あったが堂々としていた。彼女の歩みとと もに摇れ動くテーラー仕立てのコートとハ イヒール。リータは今でもファッション誌の 1 ページから抜け出たような人だ。

Alison Abbott は、Nature の上級ヨーロッパ特派員。

1. Hamburger, V. J. Exper. Zool. 68, 449-494 (1934)

2. Levi-Montalcini, R. \& Levi, G. Arch. Biol. Liege 54, 189-200 (1943).

3. Levi-Montalcini, R. Ann. N. Y. Acad Sci. 55, 330-343 (1952).

4. Cohen, S. J. Biol. Chem. 237, 1555-1562 (1962).

5. Levi-Montalcini, R.\&Booker, B. Proc. NatlAcad.Sci. USA 46, 384-391 (1960).

6. Angeletti, R. H. \& Bradshaw, R. A. Proc. Natl Acad. Sci. USA 68, 2417-2420 (1971)

7. Levi-Montalcini, R. et al. Progr. Neuroendocrinol.3,1-10 (1990).

\section{Nobel laureate celebrates her centenary}

\section{0歳の祝賀式典}

Nature Vol. 458(1090)/30 April 2009

イタリアの神経科学者リータ レビ - モンタルチーニ博士が、 4月 22 日、ノーベル賞受賞者 として初めて 100 歳の誕生日
を迎えた。彼女を祝う一連の 科学ミーティングの中で、イタ リアのジェルミー二教育相は、

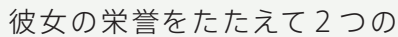

プレゼントを贈ると表明した。 その1つは、リータが創立 し、現在財政的危機に陥って いるヨーロッパ脳科学研究所 EBRI に対して、1 回限りでは あるが総計 50 万ユーロ(65 万米ドル）の資金を提供する こと。2つ目は、これまた彼 女の名前をとったプログラムに 対して、6 億ユーロを供出す ること。このプログラムは、海 外で研究してイタリアに戻った
若い研究者に対して 3 年間の 奨学金を贈っている。

多くの科学者が「これでは 大海の一滴にすぎない」と批 判する中で、リータは「政府 のこのような対応は、私が想 像せざるを得なかった厳しい 状況よりは、はるかにましなも のです」と語った。ほぼ 1 週 間にわたって行われた公式行 事の中でも、彼女は疲れを見 せるようなことはなかった。 